\title{
MTSAT観測より推定した雲頂高度情報を用いた 雲微物理データ同化手法の高度化 IMPROVING A CLOUD MICROPHYSICS DATA ASSIMILATION TECHNIQUE USING CLOUD TOP HEIGHT INFORMATION ESTIMATED FROM THE OBSERVATION BY MULTI-FUNCTIONAL TRANSPORT SATELLITE
}

\author{
谷口健司 1 ・ Cyrus Raza Mirza ${ }^{2}$ ・ 小池俊雄 ${ }^{3}$ \\ Kenji TANIGUCHI, Cyrus Raza MIRZA and Toshio KOIKE \\ 1正会員 工博 金沢大学 理工研究域環境デザイン学系 特任助教（テ920-1192 石川県金沢市角間町） \\ 2正会員 工博 東京大学大学院 工学系研究科（干113-8656 東京都文京区本郷七丁目3-1） \\ 3 正会員 工博 東京大学大学院 工学系研究科 教授（干113-8656 東京都文京区本郷七丁目3-1)
}

\begin{abstract}
To improve water vapor and cloud liquid water content in a numerical weather prediction model, Cloud Microphysics Data Assimilation System (CMDAS) was developed. CMDAS improves an atmospheric condition by assimilating the brightness temperature data observed by the Advanced Microwave Scanning Radiometer for Earth Observing System (AMSR-E). In the optimization scheme of CMDAS, a number of combinations of integrated water vapor and cloud water content are firstly given and those integrated values are vertically distributed depending on cloud top height (CTH). Using those vertical profiles, CMDAS searches the optimal atmospheric condition through a model operator and an observation operator. In the original CMDAS, a constant value is used as CTH. In this study, a horizontal distribution of CTH estimated from Multi-functional Transport Satellite (MTSAT) observation is applied to CMDAS and the effects of CTH information which is temporally and spatially consistent are examined.
\end{abstract}

Key Words : data assimilation, satellite observation, water vapor, cloud liquid water content, cloud top height, precipitation

\section{1. 研究の背景及び目的}

頻発する集中豪雨による洪水被害軽減の必要性は，近 年一層高まっており，2010年には関東・近畿・東海・北 陸の4つの地域においてXバンドMPレーダの試験運用が 開始された.リアルタイムでの詳細な降水量・降水分布 情報の収集によって，防災対応力の向上が期待される.

一方, 数值気象モデルによる降水予測情報も洪水被害軽 減のためのソフト対策実施には不可欠な要素である. 降 水予測精度向上には，衛星観測によって得られる広範か つ一様な水蒸気等の分布情報の活用が有効と考えられる. 2002年に打ち上げられた地球観測衛星Aquaに搭載の受 動型マイクロ波放射計（Advanced Microwave Scanning Radiometer for Earth Observing System: AMSR-E) は水蒸 気及び雲水量の吸収帯を含む周波数での輝度温度を観測 し，積算水蒸気量や積算雲水量の推定に用いられている. Mirzaら（2005）は降水予測精度向上のため, AMSR-E
による観測輝度温度を同化し，数值気象モデルにおける 水蒸気及び雲水量情報を改善する雲微物理データ同化シ ステム (Cloud Microphysics Data Assimilation System: CMDAS）を開発した ${ }^{1)}$. 谷口ら（2010）はCMDASにお いて 観測演算子として用いられている放射伝達モデル の下部境界条件として, AMSR-E観測から推定される海 面水温及び海上風速を用い，適時性の高い情報が同化精 度に与える影響を検討した ${ }^{2)}$ 。また, CMDAS では雲微 物理スキームによってAMSR-E観測時刻の大気状態を求 めるが，その実行に必要な水蒸気量及び雲水量の鉛直分 布を定義する際に用いる雲頂高度の值が同化結果に大き な影響を与え, 同化領域に一様な定数を与えるという従 来の手法では不十分であることを示した．本研究では， 宇宙航空研究開発機構（JAXA）によって打ち上げられ た運輸多目的衛星 (Multi-functional Transport Satellite: MTSAT）による観測データを用いて雲頂高度を推定し， AMSR-E観測時刻付近における実際の雲頂高度分布情報 をCMDASに適用することで同化手法の高度化を図る. 


\section{2. データ同化システムの概要及び使用データ}

（1）雲微物理データ同化システム (CMDAS)

\section{a) システムの概要}

図-1にCMDASの概要を示す.CMDASでは非静力学 領域気象モデルAdvenced Regional Prediction System (ARPS) ${ }^{3)}$ を用いて第一推定值を得た後，数值計算を中 断しデータ同化を行う。最適化スキームにはShuffled Complex Evolution法（SCE-UA） ${ }^{4}$ を用いている. 最適化 スキーム内では，(1)各格子点においてランダムな積算水 蒸気量と積算雲水量の組を複数作成する; (2)各組につい て数值実験中断時刻からAMSR-E観測時刻までモデル演 算子である雲微物理スキーム (Lin Ice Scheme ${ }^{5)}$ ) を実 行し同化時刻の物理量を求める; (3)得られた物理量から 放射伝達モデルにより輝度温度を求める ; (4)得られた輝 度温度群からAMSR-E観測輝度温度との誤差の最小值を 探索する．誤差最小值が定めた閾値より小さくなるまで (1)から(4)を繰り返し，十分小さな誤差を与える積算水蒸 気量と積算雲水量を最適値とし，全領域での計算終了後， 得られた大気場を用いて数值予測を再開する，なお，陸 域のマイクロ波帯の観測輝度温度は，地表面状態により 大きく変化し，陸域大気への放射伝達モデル適用が困難 なため, CMDASの適用範囲は海洋上に限定している。

データ同化では一般に背景誤差と観測誤差の和であら わされる誤差評価関数 $\mathbf{J}$ を最小化する状態変数べクト ル $\mathbf{x}$ を定義する. 背景誤差を求めるには動的手法と統 計的手法があり，自由度の高い大気モデルでは動的手法 はうまく動作しない。 また, 積算水蒸気量や積算雲水量 に関しては, 統計的な誤差共分散行列推定に必要な解析 情報を得ることが困難である。そこで本研究ではモデル を完全と仮定して背景誤差を考慮しないこととした. 求 める誤差は観測誤差のみとなり， J は次式で表現される.

$$
\mathbf{J}=\frac{1}{2}\left(\mathbf{H}[\mathbf{x}]-\mathbf{y}_{O}\right)^{T} \mathbf{R}^{-1}\left(\mathbf{H}[\mathbf{x}]-\mathbf{y}_{O}\right)
$$

ここで， $\mathbf{H}$ は放射伝達モデル， $\mathbf{y}_{O}$ は観測輝度温度， Rは誤差共分差行列である。なお，本研究では校正済み 観測輝度温度を用いるため補正の必要はないと考え，誤 差共分散行列には単位行列を与えている.

\section{b）積算水蒸気量及び積算雲水量の鉛直分配と雲頂高度}

CMDASにおいて第一推定值から衛星観測時刻まで雲 微物理スキームを実行するには，最適化スキームでラン ダムに与える積算水蒸気量及び積算雲水量の候補值から それぞれの鉛直分布を与える必要がある。CMDASでは 積算雲水量がゼロでない場合には，雲頂高度と雲底高度 の間で放物型の分布となるように雲水量を鉛直配分寸る。 水蒸気量については，雲層では相対湿度が $100 \%$ となる よう鉛直配分し，雲層以外ではARPSから得られる鉛直 分布割合をもとに配分する（図-2）。

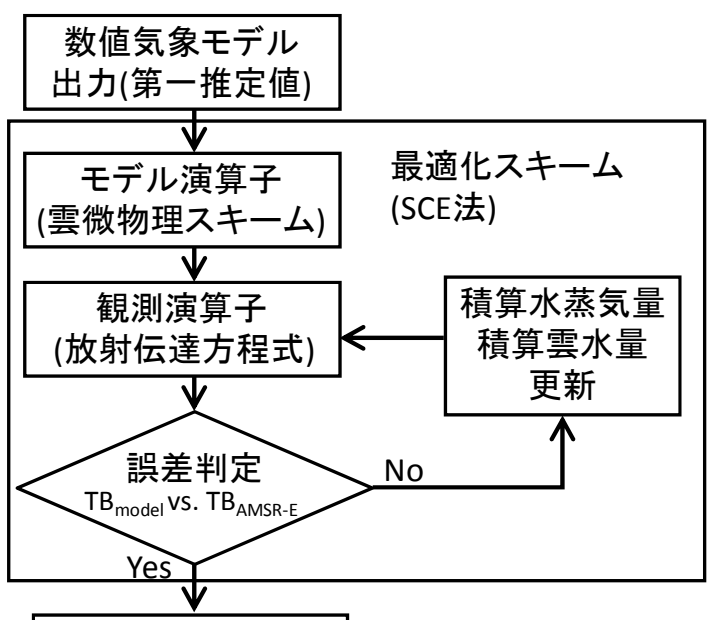

\section{数値予測再開}

図-1＼cjkstart雲微物理データ同化システムの概要

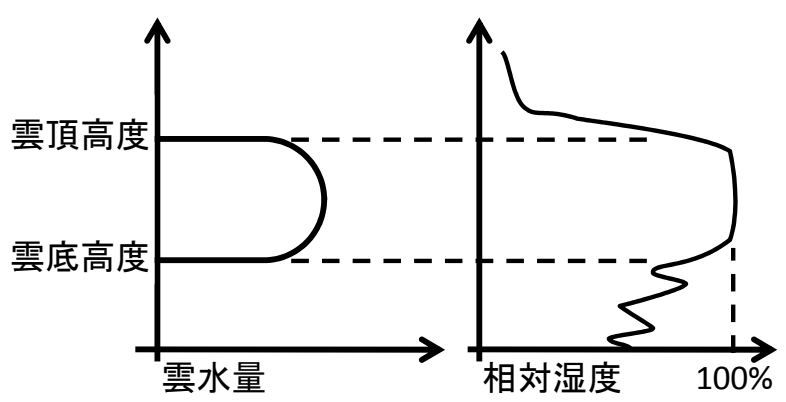

図-2 雲水量及び水蒸気量の鉛直配分方法の模式図

これまでのCMDASでは全てのモデル格子に対して雲 頂高度を $8000 \mathrm{~m}$ ，雲底高度を $1500 \mathrm{~m}$ とて与えていたが, 本研究ではMTSAT観測から推定される雲頂高度情報を 用いて各格子での水蒸気量及び雲水量の鉛直分布を決定 し，従来に比べて正確な情報を用いて雲微物理スキーム を実行し，データ同化結果の改善を図る，なお，雲底高 度に関しては従来と同様の值を与えるものとする。

\section{(2) データ}

a）AMSR-E観測データ及びプロダクト

本研究ではJAXAが開発したマイクロ波放射計AMSREにより観測された輝度温度を利用する．AMSR-Eを搭 載した地球観測衛星Aquaは太陽同期準回帰軌道を周回 し，1日2回の観測を行っている. AMSR-Eは複数周波数 帯の垂直及び水平偏波における輝度温度を観測している が，本研究では大気中の水蒸気量及び雲水量を改善する ため，主に積算水蒸気量に感度を持つ $23.8 \mathrm{GHz}$ 及び主に 積算雲水量に感度を持つ $89.0 \mathrm{GHz}$ の輝度温度を用いる

放射伝達モデルの下部境界条件に必要な海上風速には, AMSR-E観測から推定された全天候型海上風速を用いる。 全天候型海上風速はJAXA標準と異なるアルゴリズムで 算出されたもので，降雨時でも推定される，谷口ら

（2010）は標準アルゴリズムによる海上風速を欠損時に は補完して用いていたが，本プロダクトでは補完の必要 が無く，適時性の高い情報を活用寸ることが可能である. 
表-1 各同化実験の概要. 時刻はUTC.

\begin{tabular}{|l|c|c|c|}
\hline & $\begin{array}{c}\text { 対象日 } \\
\text { (年月日) }\end{array}$ & $\begin{array}{c}\text { 数值実験 } \\
\text { 中断時刻 }\end{array}$ & $\begin{array}{c}\text { AMSR-E } \\
\text { 観測時刻 }\end{array}$ \\
\hline CASE-1 & 20080902 & $16: 30$ & $16: 56$ \\
\hline CASE-2 & 20081117 & $17: 00$ & $17: 22$ \\
\hline CASE-3 & 20070704 & $04: 00$ & $04: 17$ \\
\hline
\end{tabular}

\section{b) MTSAT観測データ}

2005年に打ち上げられたMTSATでは可視・赤外あわ せて5つのチャンネルによる観測が実施されている．本 研究では，高層雲の観測に有効な $11 \mu \mathrm{m}$ 帯の波長（赤外 1 チャンネル：IR1）による輝度温度及び可視チャンネル から得られるアルベドを用いて雲頂高度を推定する。

\section{3. 実験概要}

\section{（1）対象イベント及び同化スケジュールの概要}

本研究では，AMSR-E観測時刻の数時間後から降水が 生じ，降水が連続する期間における最大時間降水量が $10 \mathrm{~mm} / \mathrm{h}$ を超える降水イベントを3ケース選定し，同化実 験対象とした（実験領域は図-3を参照）。実験対象とし た降水イベントをCASE-1〜3とし，概要を表-1に示す. 表-1の実験中断時刻はARPSによる第一推定值を得る時 刻であり，そこからAMSR-E観測時刻まで同化を行う。

\section{（2）MTSAT観測データを用いた雲頂高度推定}

雲頂高度はMTSAT観測データ及び気象庁による現業 ラジオゾンデ観測データより推定する．MTSATの各観 測格子の輝度温度とラジオゾンデ観測より得られる温度 プロファイルを比較し，対応する高度を雲頂高度として 決定する．ラジオゾンデ鉛直気温分布は輪島での観測 データを用いる．なお，ラジオゾンデ鈆直気温分布は指 定気圧面及び特異点のみで定義されているため，実際に は輝度温度が含まれる温度範囲を特定し，その範囲での 温度と高度変化が線形であると仮定して内挿し雲頂高度 を決定する．日中の観測データに対しては，MTSATの 可視チャンネルから求められるアルベドの值が 0.25 以下 である場合には雲が存在しないとして，雲頂高度を定義 しないものとした．夜間は可視チャンネルが利用できな いため，IR1輝度温度分布と比較しながら雲頂高度の閾 值を決定し，それ以下の領域では雲は存在しないものと した. 図-3にCASE-1〜3で推定した雲頂高度分布を示す。 ラジオゾンデ観測は国内においては16か所で実施され ているが，同化対象領域において利用可能なデータは輪 島で観測されたもののみであり，適用に当たっては温度 プロファイルの空間代表性が問題となる。図-4aは CASE-1の第一推定值の6250mの高度における気温分布 であるが，日本海側の陸域付近と海洋上の最も気温の低 い領域の温度差は6〜 7K程度である. 本研究ではラジオ a) CASE-1

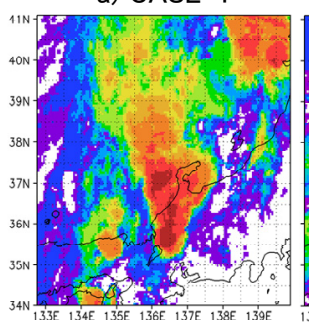

b) CASE-2

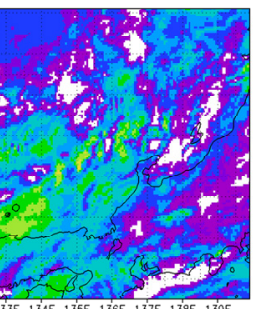

133E 134E 135E 136E 1375 139E 1305

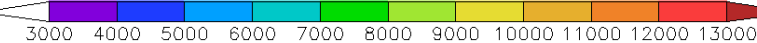

図-3 MTSAT及びラジオゾンデ観測より推定された 雲頂高度分布 $(\mathrm{m})$ a) 気温分布

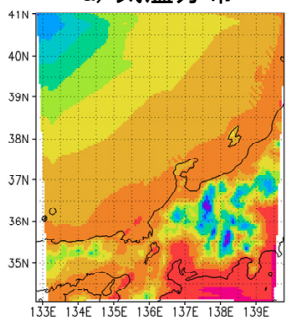

b) 雲頂高度

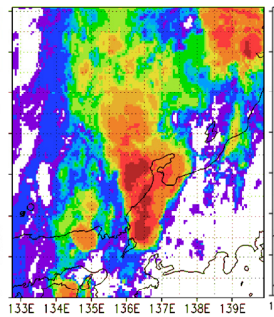

c) 雲頂高度の差

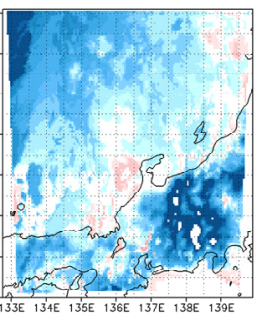

\section{$\begin{array}{lllllllllll}257 & 258 & 259 & 260 & 261 & 262 & 263 & 264 & 265 & 266 & 267\end{array}$}

図-4 CASE-1に関するa)第一推定值による気温分布, b) 第一推定值による気温を用いて推定した雲頂 高度分布, c) 図-3a及び図-4bの差. カラーバー は上段が気温 $(K)$ ，下段が雲頂高度の差 $(m)$.

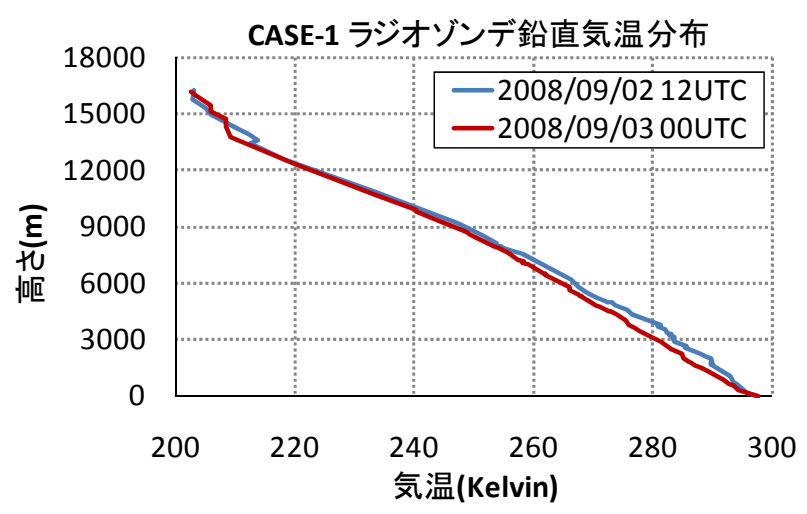

図-5 CASE-1の同化時刻前後での輪島における ラジオゾンデ観測による鉛直気温分布.

ゾンデ観測データの他に，ARPSによる第一推定值とし て得られる気温データより推定した雲頂高度を用いた同 化実験も併せて行う。図-4b，c にCASE-1での第一推定 值による気温を用いて推定した雲頂高度分布，及びラジ オゾンデ観測を用いて推定した雲頂高度との差を示す。

ラジオゾンデ観測は世界標準時0時と12時に実施され， 同化時刻とは数時間のずれが生じてしまう。CASE-1の 同化時刻前後のラジオゾンデ鉛直気温分布を確認したと ころ，両者の差は小さかった（図-5）。CASE-2及び CASE-3についても同化時刻前後の鉛直気温分布の差は 小さかった（図は省略）ことから，適切な時間代表性が あるとしてラジオゾンデ観測を用いることとした。 
表-2 CASE-1の同化実験における観測輝度温度と同化 後の輝度温度の誤差の平均値亡標準偏差 $(\mathrm{K})$. Default, MTSAT, MTSAT_Aについて23GHz及び 89GHzの水平偏波に関する結果.

\begin{tabular}{|c|c|c|c|}
\hline & Default 23 & MTSAT 23 & MTSAT_A 23 \\
\hline 平均誤差 & 2.73 & -1.98 & -1.95 \\
\hline 標淮偏差 & 10.62 & 9.01 & 8.97 \\
\hline \hline & Default 89 & MTSAT 89 & MTSAT_A 89 \\
\hline 平均誤差 & -5.93 & -5.45 & -5.47 \\
\hline 標準偏差 & 17.14 & 15.61 & 15.93 \\
\hline
\end{tabular}

a) $23 \mathrm{GHz}$ 水平偏波

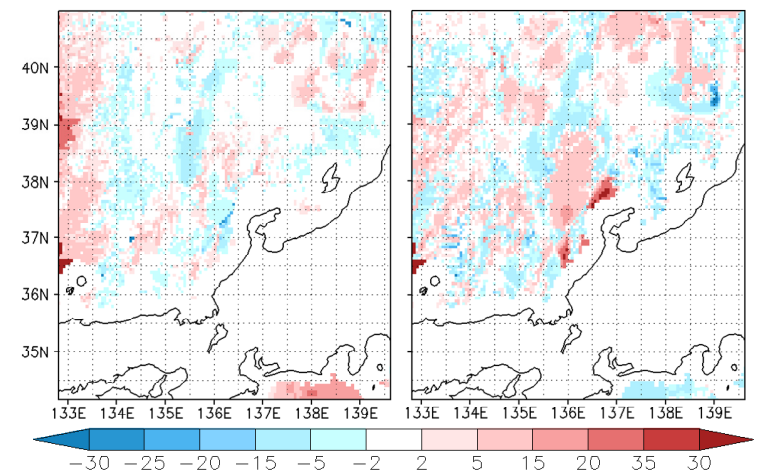

図-6 CASE-1-DefaultとCASE-1-MTSATの同化後の 輝度温度の誤差の絶対値を求め, さらに 両者の差をとったもの. a) 23GHz水平偏波, b) $89 \mathrm{GHz}$ 水平偏波. 単位はK.

雲頂高度の推定については, 海面付近での輝度温度と 実温度の差が最大で10K程度あり，これを考慮した方法 や，水蒸気チャンネルを活用した方法も提案されている が》，本研究では比較的簡易な手法で推定した雲頂高度 情報用いて，その同化結果への影響を調べることとした．

\section{4. データ同化結果}

CASE-1 3では従来の雲頂高度（8000m）, MTSAT及 びラジオゾンデ鉛直気温分布から推定した雲頂高度, MTSAT及びARPSによる第一推定值の気温から推定した 雲頂高度の3つの同化実験を行った，以下，C1-Default, C1-MTSAT，C1-MTSAT_Aのように表記する.

\section{(1) CASE-1}

表-2はCASE-1における各同化実験に関して, 同化後 の輝度温度とAMSR-E観測による輝度温度の差について 海上の全領域での平均誤差と標準偏差を $23 \mathrm{GHz}$ 及び 89GHz水平偏波に関して示したものである. 結果を比較 すると，MTSAT雲頂高度を用いた場合で小さく，わず かだが同化結果が改善されている。一方, 図-6はC1Default $と C 1-M T S A T の$ 同化後の輝度温度の誤差を求め, さらに両者の絶対值の差を求めたものである．正の值は

\section{a) $23 \mathrm{GHz}$ 水平偏波 $\quad$ b) $89 \mathrm{GHz}$ 水平偏波}
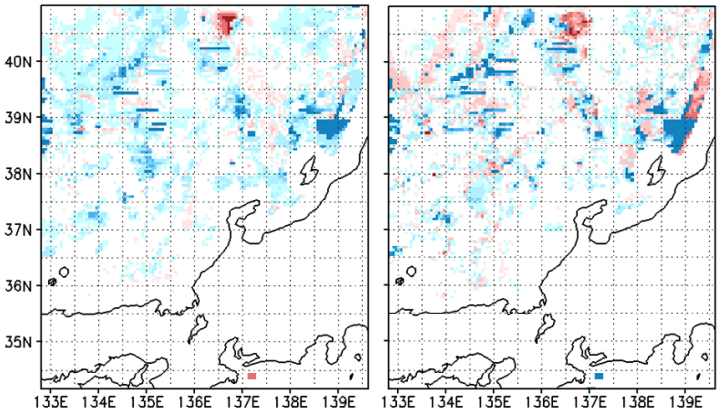

図-7 CASE-2に関する図-5と同様の結果.

a) $23 \mathrm{GHz}$ 水平偏波 b) $89 \mathrm{GHz}$ 水平偏波
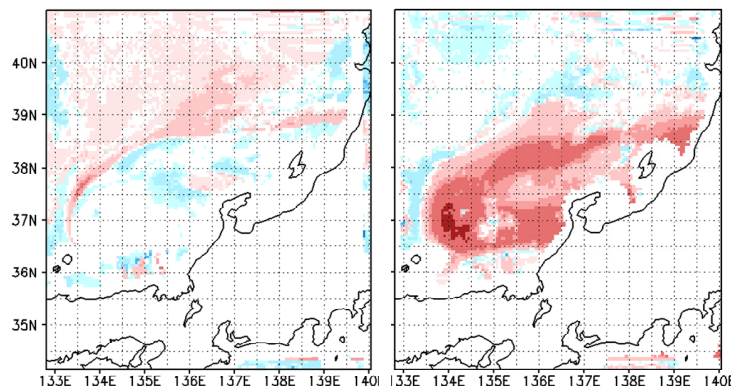

図-8 CASE-3に関する図-5と同様の結果.

C1-Defaultの誤差が大きいことを表す．23GHzでは，対 象範囲の西側境界周辺で顕著な違いがみられる。この領 域ではMTSAT観測から推定した雲頂高度は従来の值

（8000m）に比べ非常に小さい（4000m以下）か，又は 雲が存在していない（図-3a）。雲層が薄い場合や雲が 無いグリッドでは積算雲水量が小さい，またはゼロとな り，水蒸気の鉛直配分時に飽和した層が薄いか又は存在 せず，水蒸気に感度をもつ $23 \mathrm{GHz}$ の同化に大きな影響が あると考えられる。一方，背の高い雲がある領域では MTSAT雲頂高度による誤差の拡大がみられる．背の高 い雲の領域では相対湿度が100\%となるよう水蒸気が配 分され, 第一推定值による気温によっては実水蒸気量と の間に大きな差が生じる可能性がある，現在のCMDAS では温度場の改善は行わないため,この点については今 後の検討が必要である.89GHzについては，主として高 層雲領域でC1-MTSATの同化結果が改善されている. 雲 が存在していない領域では，誤差が大きくなっている. 雲が存在しない領域においては雲水量をゼロとしている が，実際には完全にゼロでない可能性もあり, 最適化ス キーム内での雲水量決定手法の改善が必要である.

C1-MTSAT_Aの同化結果はC1-MTSAT とほぼ同様で あった．表-2に示すように平均誤差及び標準偏差につい ても両者の差は非常に小さく, CASE-1においてはラジ オゾンデを用いる場合とARPSによる気温分布を用いる ことの差は非常に小さかった.

\section{(2) CASE-2}

図-7はC2-Default及びC2-MTSATに関する図-6 と同様 の結果である. $23 \mathrm{GHz} ， 89 \mathrm{GHz}$ ともMTSAT雲頂高度を 
表-3 CASE-2の同化実験における観測輝度温度と同化 後の輝度温度の誤差の平均值と標準偏差 $(\mathrm{K})$.

\begin{tabular}{|c|c|c|c|}
\hline & Default 23 & MTSAT 23 & MTSAT_A 23 \\
\hline 平均誤差 & -1.70 & -4.97 & -7.84 \\
\hline 標淮偏差 & 6.41 & 9.18 & 11.14 \\
\hline & Default 89 & MTSAT 89 & MTSAT_A 89 \\
\hline 平均誤差 & -4.85 & -6.53 & -11.06 \\
\hline 標準偏差 & 11.43 & 14.80 & 18.78 \\
\hline
\end{tabular}

表-4 CASE-3の同化実験における観測輝度温度と同化 後の輝度温度の誤差の平均值と標準偏差 (K)

\begin{tabular}{|c|c|c|c|}
\hline & Default 23 & MTSAT 23 & MTSAT_A 23 \\
\hline 平均䛊差 & 12.97 & 13.39 & 13.67 \\
\hline 標準偏差 & 11.88 & 12.59 & 12.79 \\
\hline & Default 89 & MTSAT 89 & MTSAT_A 89 \\
\hline 平均誤差 & -12.85 & -6.26 & -6.06 \\
\hline 標準偏差 & 17.94 & 12.05 & 11.83 \\
\hline
\end{tabular}

用いた場合の誤差が大きい，平均誤差及び標準偏差につ いても表-3に示すようにMTSAT雲頂高度を用いた場合 の誤差が大きい. 誤差が大きいのは主として雲頂高度が 従来の值よりやや小さい $(4000 \sim 5000 \mathrm{~m})$ 領域である. こうした領域はC1-MTSATでも誤差が大きく，水蒸気量 及び雲水量の配分手法等の再検討が必要と考えられる.

C2-MTSAT Aについては，C2-MTSATよりも平均誤 差及び標準偏差とも大きい（表-3）。特に陸域から遠く 気温が低い（雲頂高度が低い）領域において誤差が顕著 であった. これについても, 低層雲領域での水蒸気量・ 雲水量配分方法が原因と考えられる.

\section{(3) CASE-3}

図-8はC3-Default及びC3-MTSATに関して図-6 と同様 の結果を示したものである. $89 \mathrm{GHz} ゙$ は本州寄りの広い 範囲でC3-MTSATの誤差が小さい. 図-3c と比較すると 雲頂高度が $11000 \mathrm{~m}$ 以上の領域で誤差が著しく小さく, 平均誤差・標準偏差の結果からも同化結果が改善された といえる（表-4）。23GHzにおいては領域北側の雲頂高 度が9000〜11000mの領域（図-3c）でC3-MTSATの誤差 が小さくなっているが，平均誤差・標準偏差については C3-Defaultの方が小さい. C3-MTSAT_Aの同化結果につ いては，表-4の平均誤差・標準偏差加見て取れる通り， C3-MTSATと大差がなかった.

\section{5. 降水予測結果}

数值予測実験による雨域の再現性を定量的に評価する ため, 以下の式で定義される適中率 $P$ を求めた.

$$
P=\left(N_{r r}+N_{c c}\right) / N_{\text {Grid }}
$$

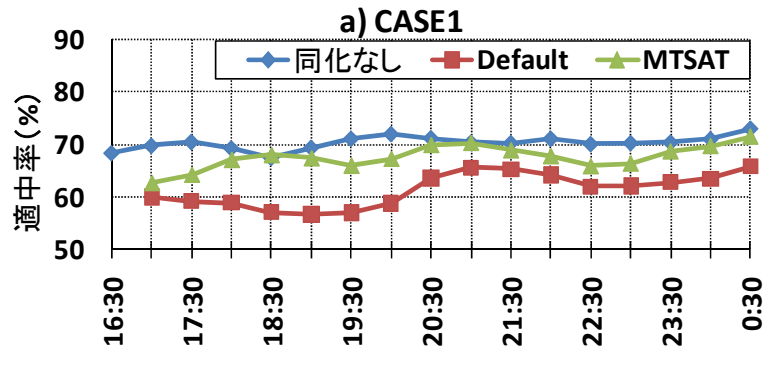

b) CASE2

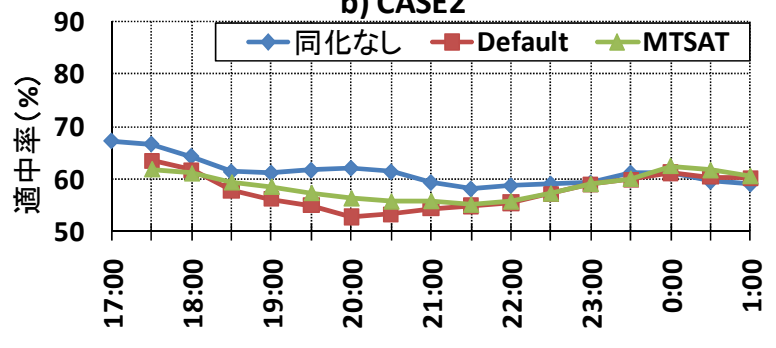

c) CASE3

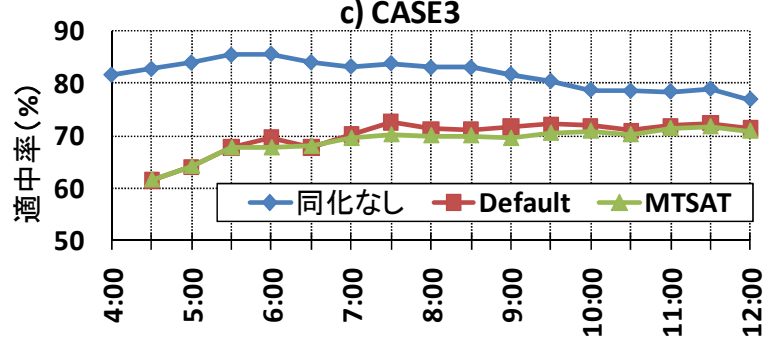

図-9 CASE1 3の予測再開から8時間後までの降水 予測実験結果の適中率 (\%) . 時刻はUTC.

ここで， $N_{r r}$ は観測・予測ともに降水が生じた格子点数, $N_{c c}$ は観測・予測ともに降水がない格子点数， $N_{\text {Grid }}$ は観 測が久測である場合を除いた計算領域の全格子点数であ る. 観測データにはレーダアメダス解析雨量を用い, 数 值計算の格子点に合わせて空間平均化処理を行った.

図-9aはCASE-1の予測再開時刻から8時間後までの雨 域予測適中率の時系列である. 同化なし, C1-MTSAT, C1-Defaultの順に適中率が高い. C1-Default, C1-MTSAT では予測再開から時間を経るにつれて適中率が高くなる 傾向がみられる. CMDASでは予測再開時刻での水蒸気 量と雲水量の值を改善するが，他の変数は第一推定值の ままであり，バランスが取れていない大気状態となる. このため予測再開直後には予測精度が低下寸るスピンダ ウンが生じる.C1-MTSATでは予測再開数時間後以降に 同化なしと同程度の的中率となる時刻もみられる.

CASE-2では予測再開1時間半後から4時間後まではC2MTSATがC2-Defaultに比べやや適中率が高いが，それ以 外の時刻では同程度の適中率である（図-9b)，予測再 開直後のスピンダウンの影響はCASE-1に比べると小さ い. 予測再開から6時間後までは同化なしによる適中率 が最も高いが，6時間後以降は3者とも同程度である.

CASE-3ではC3-Default とC3-MTSATの適中率は同程度 か，わずかにC3-Defaultが高い。予測再開直後は同化な しとC3-Default及びC3-MTSATとの適中率の差が大きい が，時間を経るに従い差が小さくなっている. 
図-10にCASE-1に関するレーダアメダス解析雨量，同 化なし及びC1-MTSATの同化結果を用いた場合の数值予 測実験による降水量分布を示寸，示した数值実験結果は 実験再開から 2 時間後の結果であり, 同化なしとC1MTSATの雨域予測適中率は同程度である（図-9a）。同 化なしのケースでは海洋上の雨域はわずかであるのに対 し，C1-MTSATでは実際の降水分布のように海洋上に広 く降水域が分布している. CASE-2及びCASE-3では同化 なしと同化ありでの適中率がほぼ同じ又は差が比較的小 さい時刻での雨域の分布は類似していた．現在の数值気 象モデルでは正確な雨域の予測には限界があり, 特徽を 捉えていてもわずかな位置のずれによって適中率は低下 する可能性があるため, 適中率と併せて，空間的な分布 特性を考慮した降水予測精度評価が必要である。

\section{6. まとめ}

本研究では雲微物理データ同化システム (CMDAS) において，雲水量及び水蒸気量の鈆直配分を決定する際 にMTSAST観測データより推定した雲頂高度を用いて同 化結果の改善を図り，降水予測精度への影響を調べた.

従来の定数 $(8000 \mathrm{~m})$ より雲頂が高い領域では, 雲水 量に感度を持つ89 $\mathrm{GHz}$ の周波数帯で同化結果の改善がみ られた. 雲頂が高くなり上層に雲水量が適切に配分され たためと考えられる. 一方, 水蒸気に感度を持つ $23 \mathrm{GHz}$ では誤差が拡大した。雲層では相対湿度が $100 \%$ となる よう水蒸気量を定義するが, 気温によっては実際の水蒸 気量との誤差が拡大寸る可能性があり, 同化過程で気温 分布の最適化を行う必要性が示唆された. 従来の雲頂よ り非常に低いか雲がない領域では23GHzで改善がみられ， 89GHzでは誤差が拡大した。低い雲頂高度や雲がない場 合，雲水量がゼロとなる層が増加するが，実際には完全 にゼロではないと考えられ，それが誤差の原因と考えら れる. 雲頂高度がやや低い領域では $23 \mathrm{GHz}$ 及び $89 \mathrm{GHz}$ もに誤差が拡大した.これらについては水蒸気量及び雲 水量の鉛直配分手法の検討と改善が必要と考えられる.

同化結果を用いた降水予測実験では，CASE-1では MTSAT雲頂高度を用いた場合に雨域予測適中率が高く なった. CASE-2及びCASE-3においては顕著な差は認め られなかった．同化しない場合の降水予測との比較では, CASE-1〜3のいずれにおいても同化なしの雨域予測適中 率が最も高かった. CASE-1では同程度の適中率でも同 化結果を用いた降水予測の方が実際の降水分布に類似し ている傾向がみられた。 また，同化結果を用いた降水予 測実験では，再開直後のスピンダウンがみられ，水蒸気 量と雲水量の変化に応じて他の物理量の修正も必要性で ある. 大気場の修正により得られる気温分布は同化過程 での水蒸気配分の改善にも活用可能と考えられ, 両者の フィードバックを含む同化システムの構築も考えられる.

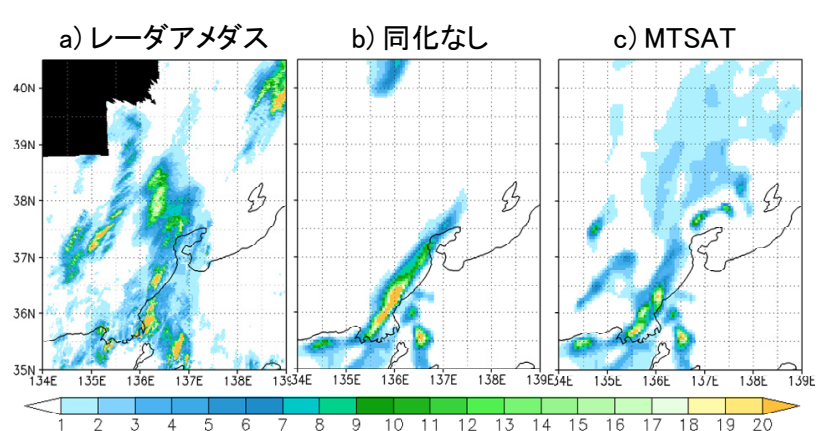

図-10 2008年9月2日18UTCの降水量分布 ( $\mathrm{mm} / 30 \mathrm{~min})$. a) レーダアメダス解析雨量（黒色は欠測值）, b）同化なし数値実験，c）C1-MTSATの同化結果 を用いた数值実験.

また，2節で述べたように，CMDASでは背景誤差及び 観測誤差を考慮していないが，時間発展を導入した同化 手法においては背景誤差の考慮により大きな改善効果が 期待され, 観測誤差推定についていくつかの手法が提案 されており ${ }^{8)}$, それらの検討と導入も今後の課題である.

謝辞 : 本研究では宇宙航空研究開発機構から提供された AMSR-E観測輝度温度及び全天候海上風速プロダクト, 高知大学より公開されているMTSATデータを利用した. ここに記して謝意を表す。

\section{参考文献}

1) Mirza, C.R., Koike, T., Yang, K. and Graf, T.: Development of 1-D Cloud Microphysics Data Assimilation System (CMDAS) by using AMSR-E Data，水工学論文集，Vol.49, pp.289-294, 2005.

2) 谷口健司, 荒木裕, C. R. Mirza, 小池俊雄: 雲微物理衛星 データ同化手法における海面水温・海上風速及び雲頂高度情 報の影響, 水工学論文集, Vol.54,pp.361-366, 2010.

3) Xue, M., Droegmeier, K.K. and Wang, V.: The Advanced Regional Prediction System (ARPS) - A multi-scale nonhydrostatic atmospheric simulation and prediction model. Part I: Model dynamics and verification, Meteorol. Atmos. Phyis., Vol.75 pp. 161193, 2000.

4) Duan, Q., Sorooshian, S. and Gupta, V.: Effective and efficient global optimization for conceptual rainfall-runoff model, Water Resources Res., Vol.28, pp.1015-1031, 1992.

5) Lin, Y-L., Farley R. D. and Orveille, H. D.: Bulk parameterization of the snow field in a cloud model, J. Climate Appl. Meteor., Vol.22, pp.1065-1092, 1983.

6) 早坂忠弘編 : 地球環境のマイクロ波リモートセンシング，日 本気象学会, 1996.

7) 隈部良司編 : 衛星からわかる気象一マルチチャンネルデータ の利用一, 日本気象学会, 2006.

8) 気象庁予報部: 数值予報課報告・別冊53号, 数值予報と衛星 データー同化の現状と課題一，気象業務支援センター， 2007.

(2010. 9. 30受付) 